\title{
A DYLAN THOMAS COMPANION
}


MACMILLAN LITERARY COMPANIONS

\author{
John Ackerman \\ A DYLAN THOMAS COMPANION
}

J. R. Hammond

AN H. G. WELLS COMPANION

AN EDGAR ALLAN POE COMPANION

A GEORGE ORWELL COMPANION

A ROBERT LOUIS STEVENSON COMPANION

\author{
John Spencer Hill \\ A COLERIDGE COMPANION
}

\author{
Norman Page \\ A DICKENS COMPANION \\ A KIPLING COMPANION \\ A CONRAD COMPANION
}

\author{
F. B. Pinion \\ A HARDY COMPANION \\ A BRONTË COMPANION \\ A JANE AUSTEN COMPANION \\ A D. H. LAWRENCE COMPANION \\ A WORDSWORTH COMPANION \\ A GEORGE ELIOT COMPANION \\ A TENNYSON COMPANION \\ A T. S. ELIOT COMPANION
}

Further titles in preparation

\begin{abstract}
Series Standing Order
If you would like to receive future titles in this series as they are published, you can make use of our standing order facility. To place a standing order please contact your bookseller or, in case of difficulty, write to us at the address below with your name and address and the name of the series. Please state with which title you wish to begin your standing order. (If you live outside the United Kingdom we may not have the rights for your area, in which case we will forward your order to the publisher concerned.)

Customer Services Department, Macmillan Distribution Ltd Houndmills, Basingstoke, Hampshire, RG21 2XS, England.
\end{abstract}




\section{A Dylan Thomas Companion}

Life, Poetry and Prose

JOHN ACKERMAN

palgrave 
All rights reserved. No reproduction, copy or transmission of this publication may be made without written permission.

No paragraph of this publication may be reproduced, copied or transmitted save with written permission or in accordance with the provisions of the Copyright, Designs and Patents Act 1988, or under the terms of any licence permitting limited copying issued by the Copyright Licensing Agency, 90 Tottenham Court Road, London W1P 9HE.

Any person who does any unauthorised act in relation to this publication may be liable to criminal prosecution and civil claims for damages.

First edition 1991

Reprinted (with corrections) 1994

Published by
THE MACMILLAN PRESS LTD

Houndmills, Basingstoke, Hampshire RG21 2XS and London Companies and representatives throughout the world

ISBN 978-0-333-60703-9 ISBN 978-1-349-13373-4 (eBook) DOI 10.1007/978-1-349-13373-4

A catalogue record for this book is available from the British Library.

Transferred to digital printing 2001 
To Barbara

and in memory of my mother 


\section{Contents}

$\begin{array}{ll}\text { List of Plates } & \text { ix }\end{array}$

Acknowledgements $\quad$ xii

$\begin{array}{ll}\text { Preface } & \text { xiii }\end{array}$

PART ONE DYLAN THOMAS'S LIFE 1

PART TWO THE POETRY

The Early Notebooks and other Manuscript Verse 57 18 Poems $\quad 75$

Twenty-five Poems $\quad 91$

The Map of Love $\quad 99$

Deaths and Entrances $\quad 106$

Collected Poems 130

Unfinished Poems $\quad 155$

$\begin{array}{lll}\text { PART THREE } & 163\end{array}$

Introduction $\quad 165$

The Early Stories 166

Portrait of the Artist as a Young Dog $\quad 180$

Adventures in the Skin Trade and

The Death of the King's Canary 200 
viii Contents

PART FOUR FILM SCRIPTS, BROADCASTS, LAST STORIES, LETTERS AND UNDER MILK WOOD

Introduction

Film Scripts and other Prose Items

Broadcasts

Quite Early One Morning

Last Stories

A Prospect of the Sea

The Collected Letters

Under Milk Wood

Appendix

Notes

Maps and Manuscript Work Sheets

1 Dylan Thomas's Swansea

2 Dylan Thomas country: southwest Wales 289

3 Dylan Thomas's Laugharne

4 Manuscript worksheets of 'The Hunchback in the Park'

5 Dylan Thomas's sketch of Llareggub

292

6 Manuscript worksheet of 'Poem on his Birthday', F. 1

7 Manuscript worksheet of 'Poem on his Birthday', F. 2

8 Manuscript worksheet of 'Poem on his Birthday', F. 3

295

9 Manuscript worksheet of 'Poem on his Birthday', F. 4

296

Select Bibliography

Index 


\section{List of Plates}

1a Swansea views, c. 1920: 'This sea town was my world'. (C) Welsh Arts Council)

1b 5, Cwmdonkin Drive, Swansea. (C) Colin Shewring)

2a D. J. Thomas, Dylan's father, c. 1900, on graduation with first-class Honours in English, University College of Wales, Aberystwyth. (David Higham Associates)

2b Dylan's mother, c. 1934. (David Higham Associates)

3 Dylan as a very young boy, with his mother, his sister Nancy and a family friend. (David Higham Associates)

4a Dylan at eleven: Grammar School mile winner (Cambrian Daily Leader). (C) South Wales Evening Post)

$4 \mathrm{~b}$ and $\mathrm{c}$ Dylan and Pamela Hansford Johnson, who visited Swansea in September 1934. (The estate of Pamela Hansford Johnson)

5a Dylan with his mother in Gower, September 1934. (The estate of Pamela Hansford Johnson)

5b Dylan and Pamela on the beach, September 1934. (The estate of Pamela Hansford Johnson)

5c Family group, 1934, with Pamela Hansford Johnson, Aunt Pollie, Mrs D. J. Thomas, Uncle Dai (Minister of Paraclete Church, Mumbles), Auntie Dosie Rees and Uncle Bob. (The estate of Pamela Hansford Johnson)

6a Dylan's first London address: 5, Redcliffe Street, Chelsea. (C) John Ackerman)

$6 \mathrm{~b}$ Dylan sunbathing while living at 21, Coleherne Road, 1935.

6c Dylan aged 19, taken while staying with Pamela Hansford Johnson in Battersea, Spring 1934. (The estate of Pamela Hansford Johnson)

7a 'Sea View', Laugharne. (C) John Ackerman)

$7 \mathrm{~b}$ Dylan and Caitlin in Blashford, Hampshire, shortly after their marriage. (David Higham Associates) 
7c Dylan and Vernon Watkins in Laugharne, 1939. (C) Mrs Given Watkins)

7d Dylan and Caitlin play croquet at Heatherslade, Vernon Watkins's Gower home, 1938. (David Higham Associates)

8 Dylan having a piggy-back across the estuary at Laugharne, 1940. (C) Rupert Shepherd)

9a Wentworth Studios, Manressa Road, Chelsea. (C) The Royal Borough of Kensinston and Chelsea)

9b Dylan Thomas and his wife Caitlin look grave in Manressa Road', Chelsea, 1944. (C) Mrs Noya Brandt)

9c Dylan in 'The Salisbury' public house, St Martin's Lane, London, 1941. (C) Mrs Noya Brandt; courtesy of the Edwin Houk Gallery Inc., Chicago)

10a 'King's Head and Eight Bells', Cheyne Row, Chelsea. (C) John Ackerman)

10b Dylan Thomas reading Quite Early One Morning on the BBC Welsh Home Service, 1948. (C) BBC Enterprises)

10c Radio Times picture, 1949, of a broadcast from Swansea: Vernon Watkins, Dylan Thomas and Daniel Jones. (Courtesy of The Evening Post, Swansea)

11 Dylan and his mother at Fern Hill Farm, 1952. (C) Rollie McKenna)

12a and $b$ Mount Pleasant Chapel and the grave of Anne Jones, Dylan's aunt, at Llanybri, near Fern Hill. (C) Colin Shewring)

13a Dylan's 'water and tree room' on the cliff and The Boat House just above the beach. (C) Colin Shewring)

13b View of Laugharne estuary and Sir John's Hill from The Boat House balcony. (C) Colin Shewring)

14a Brown's Hotel, Laugharne. (C) John Ackerman)

$14 \mathrm{~b} \quad$ Dylan playing cards at Brown's, with Ivy and Ebbie Williams. (C) Rollie McKenna)

14c The Boat House and garden, and across the bay, Llanybri. Blaen Cwm and Fern Hill lie the other side of the hill. (C) Colin Shewring)

15a Dylan, Caitlin and John Brinnin on the verandah of The Boat House. (C) Rollie McKenna)

15b Family photograph, September 1953: Dylan, Llewelyn, Aeronwy, Mrs D. J. Thomas, Colm and Caitlin. (C) Rollie McKenna) 
$16 a$

Dylan in his writing shed, 1953. (C) Rollie McKenna)

$16 b$ Dylan directing Under Milk Wood: 'Love the words' instructed Dylan; New York, 1953.

$16 c$ Dylan Thomas's grave, St Martin's churchyard, Laugharne. (C) John Ackerman)

The author and publishers wish to state that they have attempted to trace all the copyright holders, but in any case where they may have failed, they will be happy to make the necessary arrangements at the first opportunity. 


\section{Acknowledgements}

The author and publishers wish to thank the following who have kindly given permission for the use of copyright material:

J. M. Dent and the Trustees for the Copyrights of Dylan Thomas, for the extracts from: Dylan Thomas, Collected Stories; Dylan Thomas, The Doctor and the Devils; Dylan Thomas, Notebooks of Dylan Thomas; Dylan Thomas, Portrait of the Artist as a Young Dog; Dylan Thomas, Quite Early One Morning; Dylan Thomas, Selected Letters and The Collected Letters; Dylan Thomas, Under Milk Wood; Dylan Thomas, Collected Poems: 1934-1952 (1952) and Collected Poems: 1934-1953 (1988). The following poetry extracts from Dylan Thomas, The Poems, ed. Daniel Jones, are also quoted by permission: 'Missing', 'Your Breath Was Shed', and extracts from 'Notes' to the poems.

The Trustees for the Copyrights of Dylan Thomas, for the extracts from 'Twelve Hours in the Streets'; the extracts from the holograph manuscript of 'A Story' and 'Oh Pain Consumed Him, Pain Made Skin and Bone and Spirit' from Notes on Basildon Bond NotePad, copyrights by the Trustees for the Copyrights of Dylan Thomas, (C) 1990.

Permission was also given by Martin Secker \& Warburg Ltd, for the extracts from Caitlin: A Life with Dylan Thomas by Caitlin Thomas with George Tremlett.

The author is also grateful for the use of material at the National Library of Wales, Swansea Public Library, and of course for quotations from books and articles as listed. I owe a particular debt to Professor Barbara Hardy and Aeronwy Thomas, both of whom read the proofs and made helpful comments. 


\section{Preface}

I remember hearing of Dylan Thomas's death on the early morning news on Tuesday, 10 November 1953. I was then studying English at King's College, London, and had a copy of the recently published Collected Poems, few, if any, I fully understood. I immersed myself in his verse and was fortunate in being able to research on him, writing a thesis on his life and work, the first, it seems, in a British university, and more importantly the first that investigated his Welsh background. I was fortunate, too, in receiving the help and friendship of Vernon Watkins, also in meeting Mrs Caitlin Thomas at the Boat House in the summer of 1956, and Dylan's mother there the following year. Vernon Watkins was then editing Dylan Thomas's letters to him, and I now recall with gratitude and delight those talks with Vernon, touching on the work of both poets. One afternoon, too, joined by Rollie McKenna, we visited and photographed Dylan's Swansea scenes. I treasure also memories of those first visits to Laugharne, and to Fern Hill, the Dylan Thomas industry then still in its infancy, that provided reliable glimpses into the poet's life and work there, in contrast to the legends fostered in the years immediately following his death, the legend and the life running together in the popular mind. This was, of course, before the publication of Caitlin Thomas's books, always deeply rewarding in their accounts of the poet. Swansea, some seventeen miles from Maesteg where I lived, was already familiar territory, as the nearest large shopping centre, scene of cricket matches and, with Gower, the place for day-trips to the beaches. Consequently my involvement with Dylan Thomas and his world, both personal and academic, has its roots in this time; though the present book subsumes and indeed supersedes my previous studies of the poet. The kaleidoscope of criticism constantly changes the pattern and picture. The still-growing popularity of Dylan Thomas both as poet and prose writer, the sustained academic interest in his work, and the astonishing spell the legend casts even today are matters that this book raises. 
Apart from Stanford's Dylan Thomas (1954), still a helpful exposition of his work, there was little useful critical guidance in the mid-fifties as to the meaning of the poems, one American critic recommending classical astrology as the key, while Treece's book was unkindly, though not entirely unfairly, dismissed by Dylan's reported 'You cannot see the wood for the Treece'. Yet I was convinced that Dylan Thomas's poetry could be consistently interpreted and explicated, that the then-current view that his poetry was a kind of rhetoric that didn't yield to analysis, probably produced when drunk, was as much a falsification as the tales concerning the poet's life that then dominated, and still occasionally prejudice, discussion of the work. But here I must admit an interest. No doubt my view derived from an undergraduate's devotion to Dr Leavis's method of textual analysis, despite the fact that after an hour's lecture on modern poetry largely spent dismissing Auden's verse, the great man responded to the proselyte's anxious question as to how he rated Dylan Thomas with the curt 'Auden at least had talent!' Likewise, replying to a letter in 1954, he expressed surprise 'at the suggestion that Auden and Dylan Thomas could be grouped with Eliot \& Yeats \& major poets'. Despite these magisterial rebukes I was young enough to persist in my belief concerning Dylan Thomas! Nevertheless, academic and critical games of valuation and devaluation have increasingly seemed pointless beside the critic's proper task of understanding and illumination. In this respect, elucidation of the poetry still strikes me as the essential need of Dylan Thomas criticism. Accounts of the life are incidental to this, and are most worthwhile when they assist it.

As late as 1952, in reply to a query regarding the importance of Wales for him as a writer, Dylan Thomas humorously quipped, 'if I had been born and brought up in an igloo and lived on whales, not in it ... it would have been extremely unlikely had I become a writer'. The late Professor William Armstrong crucially advised me in 1955 to research Dylan Thomas's work in relation to his Welsh background. Knowledge of the Welsh background is now regarded as essential in understanding Dylan Thomas's work, and AngloWelsh literature provides one of the literary contexts of Dylan Thomas's world. Meetings with Gwyn Jones and Keidrych Rhys, editors of the Welsh Reviezv and Wales, and Glyn Jones, all three writers who knew Dylan, assisted my pioneering study of the Welsh background in Dylan Thomns: His Life and Work (Oxford 
University Press, 1964). An invitation to prepare and write the Catalogue for the Welsh Arts Council Exhibition 'Welsh Dylan', held to commemorate the twentieth anniversary of the poet's death, meant focusing on a visual introduction to the poet's life and work, and led to the later book Welsh Dylan.

It was recent doctoral research on the role of nature in Dylan Thomas's poetry that helped me to understand how his concept of nature determined both style and theme. Consequently the present book seeks to show, through analysis of the early manuscript verse, the emergence of Thomas's distinctive poetic voice in 18 Poems, a crystallisation of themes and style evolved over four years. As with Wordsworth and T.S. Eliot, an original sensibility found expression on first publication. The following account of 18 Poems, Trventy-five Poems and The Map of Love outlines the main themes in the early poetry and the movement towards greater clarity, again with the help of his letters and miscellaneous critical comment. Examination of Deaths and Entrances highlights Dylan Thomas as the first great civilian war poet, analyses his important childhood poems, and traces the lyrical pantheism of his later verse. Finally, discussion of the new poems in Collected Poems, together with the unfinished versions of 'In Country Heaven' and 'Elegy' now included in Dylan Thomas: Collected Poems 1934-53, explores the widening role of nature, with reference both to the natural life of land, sea and air that crowds the canvas of the final verse and the intensity of his pantheistic vision. The book demonstrates, too, how the last poems, like the contemporaneous Under Milk Wood, marked a threshold of new development and certainly not a diminution of inspiration.

The latter part of the book traces Thomas's growth as a prose writer, commenting on each of his works, and showing how throughout his life this was linked with his development as poet. His early experiences as an amateur actor, his wartime employment writing film scripts, his work for radio as broadcaster and writer, and his increasing fame as a reader, both of his own and others' work, cast their perspectives on his changing prose style. Attention is given to his various critical writings, as well as his letters. There is some quotation from work not previously available, such as his typescript summary of the projected 'Book of the Streets', manuscript versions of 'A Story', and some wartime comments on Chelsea that seem to me to be Dylan Thomas's. As well as discussing its themes, characters, style and structure, the 
account of Under Milk Wood traces literary and biographical sources, some not before explored. The range of his prose, and its later new directions in film scenarios and radio broadcasts as well as in drama and the short story, suggest that a notable and popular twentieth-century prose writer, as well as a great poet, was lost as a result of his untimely death.

The account of Dylan Thomas's life with which the book opens offers a picture of the worlds in which he moved: initially Swansea and west Wales, then London and return journeys to Wales, including New Quay, and finally Laugharne and America. There are glimpses of Italy, Prague, Teheran and New York, seen through his eyes. Generally I have preferred his own descriptions of places and people: they are always vivid, and often amusing. I am especially indebted to Mrs Caitlin Thomas's books, and the biographies by Constantine Fitzgibbon, Daniel Jones, Gwen Watkins and Paul Ferris. Indispensable, too, is Ferris's magisterial edition of The Collected Letters, Ralph Maud's editions of The Notebooks and Walford Davies's Dylan Thomas: Early Prose Writings. They provide the poet's words. I was finally especially fortunate to receive Dylan Thomas: Collected Poems 1934-53, and to benefit from its definitive editing by Walford Davies and Ralph Maud.

Likewise, I have sought to let the poet speak, and where I have erred I hope it is still on his side of the truth. 